\title{
The Construct of English Competence and Test Design for Non-English Major Postgraduates
}

\author{
Tinghua $\mathrm{Li}^{1} \&$ Yuwen Zhang ${ }^{1}$ \\ ${ }^{1}$ Faculty of English Language and Culture, Guangdong University of Foreign Studies, Guangzhou, China \\ Correspondence: Tinghua Li, Guangdong University of Foreign Studies, No. 2 Baiyun Avenue, Guangzhou City, \\ China.
}

Received: December 1, 2020

Accepted: December 15, 2020

Online Published: January 1, 2021

doi: 10.5539/elt.v14n1p58

URL: https://doi.org/10.5539/elt.v14n1p58

\begin{abstract}
In this study, the construct of English competence for non-English major postgraduates is defined as the ability to effectively use various strategies and comprehensively exert the ability of reading, listening, writing, speaking and translation with academic, world, linguistic and intercultural knowledge in academic activities, classroom learning and workplace. Based on this construct, an English proficiency test for non-English major postgraduates is developed.
\end{abstract}

Keywords: non-English major postgraduates, construct of English competence, test design

\section{Introduction}

By critically reviewing an array of research, it is found that the research object of most research into the construct of English competence can be subsumed into four categories: English major undergraduates (Li \& Kong, 2010; Sun, 2013; Wang, 2019), business English major undergraduates (Yan, 2012), non-English major undergraduates $(\mathrm{Xu}, 2012)$ and workers (Luan, 2019). Furthermore, most studies only focus on one aspect of the construct of linguistic competence (e.g. Campoy-Cubillo, 2019; Deane, 2013; Roger, 2008; Winke \& Isbell, 2018). Thus, it's necessary to explore the construct of English competence for non-English major postgraduates.

Additionally, the limitations of academic assessment for non-English major postgraduates can be concluded as follows: a set of evaluation standards have not been established; some tests lack guidance of language testing and educational measurement theories; diagnostic function of tests has not been greatly developed. An effective approach to solve these problems is to develop a scientific and objective test and correctly measure the learning effect of linguistic knowledge and skills. Therefore, in this study, the authors define the construct of English competence and develop a related test for non-English major postgraduates. We collected 178 competence descriptors, from which four parameters (language ability, knowledge, strategy and specific situation) are extracted to annotate and analyze the descriptors. After careful analysis, the construct of English competence for non-English major postgraduates is defined as the ability to effectively use various strategies and comprehensively exert the ability of reading, listening, writing, speaking and translation with academic, world, linguistic and intercultural knowledge in academic activities, classroom learning and workplace. Based on the construct, this study further designs appropriate question types and develops the English proficiency test for non-English major postgraduates.

\section{The Research on the Construct of English Competence}

\subsection{The Collection and Selection of English Competence Descriptors}

In this study, 30 teachers of non-English major postgraduates were recruited to describe the construct of English competence for their students, and 178 competence descriptors were collected. In order to ensure the quality of the descriptors and the operability for further study, the authors selected and revised the collected descriptors after discussion according to the following principles: 1) keeping a single descriptor for those with repeated meanings; 2) deleting unqualified descriptors; 3) revising the descriptors based on the form of "can do" statement. At last, 148 effective descriptors with high-quality are kept in the descriptor pool. 


\subsection{Descriptor Annotation Framework}

Lado (1961) first proposed the "skills+elements" language testing competence model, but he did not take communication into consideration. Chomsky (1965) ignored context factor in his view of language ability. Oller (1976) put forward "Global Language Proficiency Hypothesis", which stated that language ability should be examined through comprehensive tests, whereas native speakers' sociolinguistic competence reflected in daily use was excluded (Yan, 2012). Communicative Language Ability (CLA), which was propounded by Bachman (1990) and refined by Bachman and Palmer (1996), is seen as the most influential model in language testing field. Therefore, the annotation framework in this study is established based on CLA model and the collected descriptors. This study firstly defines the annotation framework containing five factors, namely linguistic knowledge, topic knowledge, personal traits, strategic ability, cognitive strategy and specific situations (Bachman \& Palmer, 2010). After careful annotation of descriptors, it is found that the descriptors are mostly described from the perspective of language ability instead of linguistic knowledge, thus language ability is extracted as a single factor. Meanwhile, knowledge mainly includes academic, world and linguistic knowledge. And personal traits are deleted for they hardly exist in descriptor pool. Additionally, there is no apparent distinction between strategic ability and cognitive strategy in descriptor pool, so they are combined to be strategy. According to the final framework shown in Table 1, all descriptors are annotated and the two annotated results by the two authors are analyzed, organized and combined.

Table 1. The annotation framework of descriptors

\begin{tabular}{lll}
\hline Factors & Definitions & Examples \\
\hline Language ability & $\begin{array}{l}\text { The ability to interpret and express intended } \\
\text { meanings that learners and users of English exhibit } \\
\text { when they perform language use tasks in a certain }\end{array}$ & \\
& $\begin{array}{l}\text { context or situation by applying their linguistic and } \\
\text { non-linguistic knowledge and communicative }\end{array}$ & \\
& strategies & \\
The knowledge required for performing tasks & Expertise \\
Strategy & $\begin{array}{l}\text { The planned, organized and purposeful steps and } \\
\text { methods used for performing a certain language act }\end{array}$ & Appraising \\
Specific situation & Communicative situation & International academic conference
\end{tabular}

2.3 Results of Data Analysis

Table 2 demonstrates that the majority of descriptors are about reading comprehension and written expression. Some descriptors are related to oral expression and listening comprehension. Only a minority of the descriptors cover translation ability. The results are consistent with students' practice since non-English major postgraduates need to pay more attention to reading and writing ability.

Table 2. Statistical results of language ability

\begin{tabular}{lll}
\hline Language ability & Frequency & Percentage \\
\hline Reading comprehension & 74 & $30 \%$ \\
Written expression & 70 & $29 \%$ \\
Oral expression & 49 & $20 \%$ \\
Listening comprehension & 43 & $18 \%$ \\
Translation ability & 9 & $3 \%$ \\
Total & 245 & $100 \%$
\end{tabular}

Table 3 indicates that the most important knowledge for non-English major postgraduates is academic knowledge. Only a small percentage of knowledge are concerned with world, linguistic and intercultural knowledge. The results coincide exactly with the demand for cultivating professional and academic talents with international vision at the postgraduate stage. 
Table 3. Statistical results of knowledge

\begin{tabular}{lll}
\hline Knowledge & Frequency & Percentage \\
\hline Academic knowledge & 216 & $88 \%$ \\
World knowledge & 15 & $6 \%$ \\
Linguistic knowledge & 9 & $4 \%$ \\
Intercultural knowledge & 5 & $2 \%$ \\
Total & 245 & $100 \%$
\end{tabular}

As Table 4 shows, the most frequently used strategy for non-English major postgraduates is appraising when they perform language use tasks in English. Other cognitive strategies are mainly embodied in comprehension, obtaining, summary and repair.

Table 4. Statistical results of strategies

\begin{tabular}{lll}
\hline Strategies & Frequency & Percentage \\
\hline Appraising & 103 & $42 \%$ \\
Comprehension & 41 & $17 \%$ \\
Obtaining & 37 & $15 \%$ \\
Summary & 27 & $11 \%$ \\
Repair & 25 & $10 \%$ \\
Inferring & 6 & $2 \%$ \\
Record & 4 & $2 \%$ \\
Conclusion & 2 & $1 \%$ \\
Total & 245 & $100 \%$ \\
\hline
\end{tabular}

As can be seen from Table 5, non-English major postgraduates often use English in specific situations, covering academic activities, classroom learning and workplace. Moreover, English is mostly applied whey they write academic articles.

Table 5. Statistical results of specific situations

\begin{tabular}{lll}
\hline Specific situations & Frequency & Percentage \\
\hline Writing academic articles & 109 & $56 \%$ \\
Attending academic conferences & 52 & $27 \%$ \\
Workplace & 39 & $20 \%$ \\
Attending academic lectures & 19 & $10 \%$ \\
Applying to a foreign university & 13 & $7 \%$ \\
Classroom learning & 13 & $7 \%$ \\
Total & 245 & $100 \%$ \\
\hline
\end{tabular}

2.4 Defining the Construct of English Competence for Non-English Major Postgraduates

Building upon the above analysis, the construct of communicative English competence for non-English major postgraduates can be defined as the ability to effectively use various strategies and comprehensively exert the ability of reading, listening, writing, speaking and translation with academic, world, linguistic and intercultural knowledge in academic activities, classroom learning and workplace. The construct of English competence for non-English postgraduates is shown in Figure 1. 


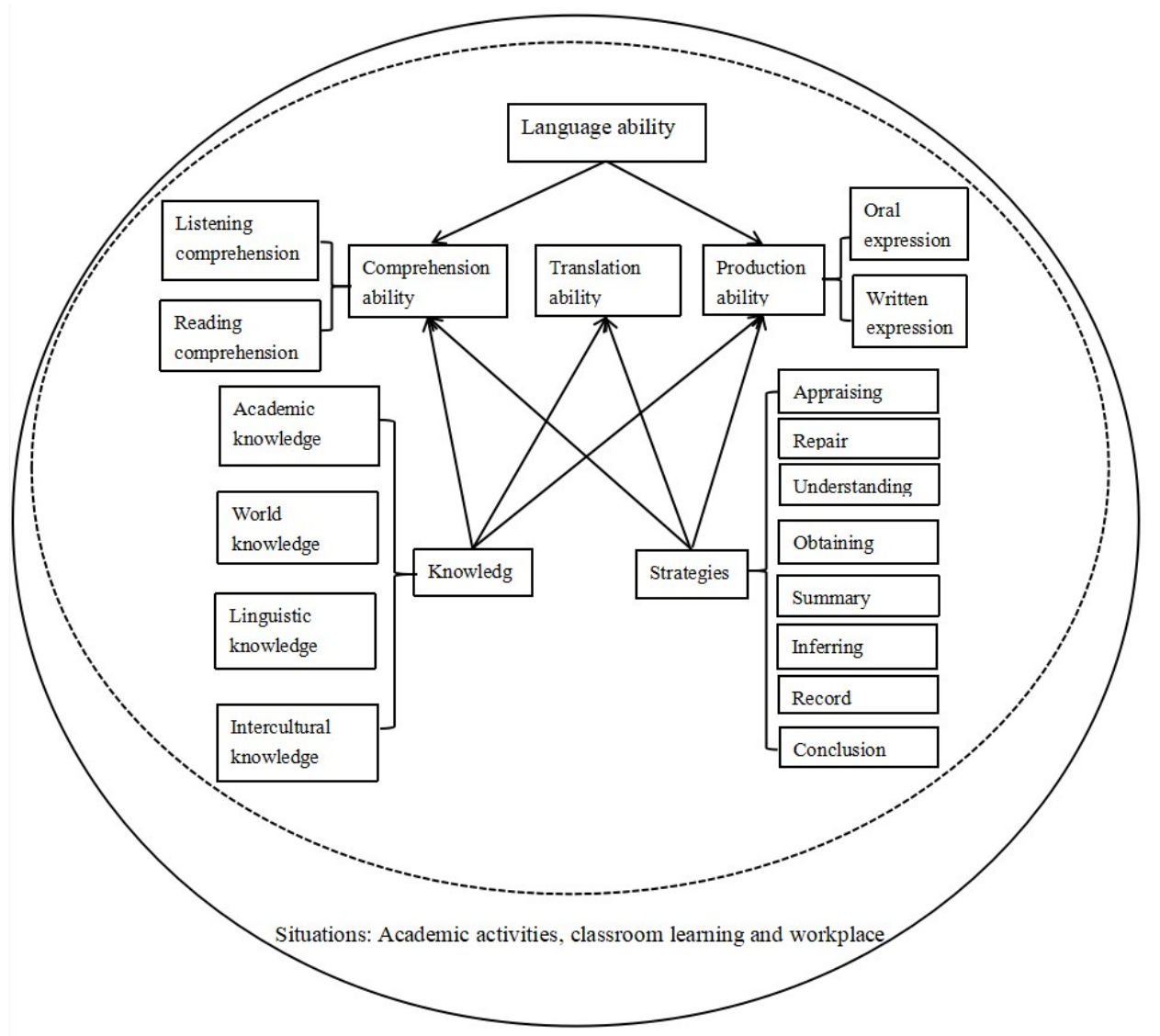

Figure 1. The construct of English competence for non-English postgraduates

\section{Question Types of the Test}

\subsection{Language Comprehension}

Language comprehension is composed of six sections: listening comprehension, viewpoints matching, lecture dictation, reading comprehension, and information contrast. The first three sections examine students' ability to obtain and process oral information through listening, and the last two sections examine students' ability to obtain and process written information through reading.

- Listening comprehension: The recorded sound material, a classroom teaching monologue with 300-400 words, is played once to allow students to fill 5 blanks in a mind map. This section intends to examine students' ability to obtain important information and specific details.

- Viewpoints matching: The recorded sound material is a discussion on an academic topic with 400-500 words and it is played once to allow test takers to match 5 figures with their own viewpoints. This section aims to appraise students' ability to understand the general idea of the material and the viewpoints of the speakers.

- Lecture dictation: The recorded sound material, a monologue of an academic lecture with 500-600 words, is played once for students to finish an outline dictation. This section aims at examining students' comprehensive ability to record key words, and obtain and summarize oral information.

- Reading comprehension: The reading material is an excerpt of an academic article with 800 words. Students are asked to write correct outlines through reading. This section is designed to examine students' ability to locate key information and summarize the main points.

- Information contrast: The reading material of 1000 words is from three university websites. Students need to fill 10 blanks based on information contrast. This section aims to assess students' ability to organize and summarize information. 


\subsection{Translation}

The purpose of this part is to test students' translation ability. It includes C-E and E-C translation. The material of C-E translation is the abstract of a journal article and that of E-C translation is a text about work.

\subsection{Language Expression}

Language expression part consists of data analysis, comprehensive writing, opinions expressing, which aims at examining the ability of students' written and oral expression.

- Data analysis: Students need to write a data analysis report for a given data table. This section pays more attention to students' ability of analysis, description and explanation.

- Comprehensive writing: Two excerpts from two academic papers on the same topic are provided for students to summarize the authors' viewpoints and then make their comments. This section aims to examine students' ability of summary, criticism and assessment.

- Opinions expressing: Students are asked to answer the questions about job hunting or college application. What's more, an expert selected from a conference paper is offered for students to answer relevant questions.

Table 6. Question types

\begin{tabular}{|c|c|c|c|c|c|c|}
\hline Parts & Sections & Material & Question types & Number & Points & Time \\
\hline \multirow{5}{*}{$\begin{array}{l}\text { Language } \\
\text { comprehension }\end{array}$} & $\begin{array}{l}\text { Listening } \\
\text { comprehension }\end{array}$ & $\begin{array}{l}\text { A classroom } \\
\text { teaching } \\
\text { monologue }\end{array}$ & Mind map & 5 & 5 & 5 \\
\hline & $\begin{array}{l}\text { Viewpoints } \\
\text { matching }\end{array}$ & $\begin{array}{l}\text { An academic } \\
\text { discussion }\end{array}$ & $\begin{array}{l}\text { Multiple } \\
\text { choice }\end{array}$ & 5 & 5 & 5 \\
\hline & Lecture dictation & $\begin{array}{l}\text { An academic } \\
\text { lecture }\end{array}$ & Dictation & 10 & 10 & 10 \\
\hline & $\begin{array}{l}\text { Reading } \\
\text { comprehension }\end{array}$ & $\begin{array}{l}\text { An academic } \\
\text { article }\end{array}$ & Outline cloze & 5 & 5 & 10 \\
\hline & $\begin{array}{l}\text { Information } \\
\text { contrast }\end{array}$ & $\begin{array}{l}\text { Information about } \\
\text { three university } \\
\text { websites }\end{array}$ & Cloze & 10 & 10 & 15 \\
\hline \multirow{2}{*}{ Translation } & $\begin{array}{l}\text { Chinese-English } \\
\text { (C-E) translation }\end{array}$ & An abstract & Translation & 1 & 10 & 15 \\
\hline & $\begin{array}{l}\text { English-Chinese } \\
\text { (E-C) translation }\end{array}$ & $\begin{array}{l}\text { A short text about } \\
\text { work }\end{array}$ & Translation & 1 & 10 & 15 \\
\hline \multirow{4}{*}{$\begin{array}{l}\text { Language } \\
\text { expression }\end{array}$} & Data analysis & $\begin{array}{l}\text { A graph from an } \\
\text { academic paper }\end{array}$ & Writing & 1 & 20 & 20 \\
\hline & $\begin{array}{l}\text { Comprehensive } \\
\text { writing }\end{array}$ & $\begin{array}{l}\text { Two excerpts } \\
\text { from two } \\
\text { academic papers }\end{array}$ & Writing & 1 & 25 & 35 \\
\hline & $\begin{array}{l}\text { Opinions } \\
\text { expressing }\end{array}$ & $\begin{array}{l}\text { A text concerning } \\
\text { job hunting or } \\
\text { college } \\
\text { application }\end{array}$ & $\begin{array}{l}\text { Oral } \\
\text { expression }\end{array}$ & 1 & 10 & 10 \\
\hline & $\begin{array}{l}\text { Opinions } \\
\text { expressing }\end{array}$ & $\begin{array}{l}\text { An excerpt of a } \\
\text { conference paper }\end{array}$ & $\begin{array}{l}\text { Oral } \\
\text { expression }\end{array}$ & 1 & 10 & 10 \\
\hline Total & & & & 41 & 120 & 150 \\
\hline
\end{tabular}

\section{Conclusion}

Nowadays, for lack of common teaching objective and teaching syllabus, there is no standard in English teaching and assessment for non-English major postgraduates. In addition, there is a big issue that the results of different tests are not comparable. Hence, with the help of language testing and educational measurement theories, the authors try to define the construct of English competence and develop the English proficiency test to facilitate 
teaching, learning and assessment.

In this article, the construct definition of English competence and test design for non-English major postgraduates may serve as a springboard for further research and practice.

\section{Acknowledgments}

We would like to thank Dr. Jin Chen for her valuable suggestions on the manuscript. This study was supported by the National Education Science "13th Five-Year Plan" 2018 Ministry of Education Youth Project (EIA180491) and the Thirteen Five-Year Plan for Philosophy and Social Sciences Project of Guangzhou (2018GZQN24).

\section{References}

Bachman, L. F., \& Palmer, A. S. (1996). Language testing in practice. Oxford: Oxford University Press.

Bachman, L. F., \& Palmer, A. S. (2010). Language testing in practice: Designing and developing useful language tests. Oxford: Oxford University Press.

Bachman, L. F. (1990). Fundamental considerations in language testing. Oxford: Oxford University Press.

Campoy-Cubillo, M. C. (2019). Functional diversity and the multimodal listening construct. European Journal of Special Needs Education, 34(2), 204-219. https://doi.org/10.1080/08856257.2019.1581402

Chomsky, N. (1965). Aspects of the theory of syntax. Cambridge: MIT Press. https://doi.org/10.21236/AD0616323

Deane, P. (2013). On the relation between automated essay scoring and modern views of the writing construct. Assessing Writing, 18(1), 7-24. https://doi.org/10.1016/j.asw.2012.10.002

Lado, R. (1961). Language testing: The construction and use of foreign language tests. London: Longman.

Li, Q. H., \& Kong, W. (2010). A research into construct of EFL writing ability of English majors in China: Perspectives of experts and raters. Foreign Language Education, 5, 76-80.

Luan, L. (2019). A constructive study of oral communication competence in workplace English. Journal of Ezhou University, 3, 66-68.

Oller, J. W. (1976). Evidence of a general language proficiency factor: An expectancy grammar. Die Neuen Sprachen, 75(2), 165-174.

Roger, A. E. (2008). Teaching the speaking skill to Japanese students part1: Construct \& Practice. The Journal of Kanda University of International Studies, 20, 235-260.

Sun, Y. (2013). Research into construct of EFL writing ability of Chinese English majors: Evaluating Compositions of TEM4 Test Takers. Technology Enhanced Foreign Language Education, 1, 48-52.

Wang, H. P. (2019). A study on the competence construct of English lecture comprehension. Foreign language education in China, 4, 49-55.

Winke, P. M., \& Isbell, D. R. (2018). Construct of listening. The TESOL Encyclopedia of English Language Teaching, 1-6. https://doi.org/10.1002/9781118784235.eelt0618

$\mathrm{Xu}, \mathrm{Y}$. (2012). An investigation into the operational definition of the construct of college English writing ability. College English Teaching and Research, 6, 70-75.

Yan, M. (2012). A study of genre-based discursive competence of business English: Construct definition and test development (Doctoral dissertation). Retrieved from https://www.cnki.net/

Yan, M. (2012). Business English competence: construct definition and test development. Contemporary Foreign Languages Studies, 2, 23-28.

\section{Copyrights}

Copyright for this article is retained by the author(s), with first publication rights granted to the journal.

This is an open-access article distributed under the terms and conditions of the Creative Commons Attribution license (http://creativecommons.org/licenses/by/4.0/). 